REVIEW

\title{
Pathophysiological aspects of Wnt-signaling in endocrine disease
}

\author{
Sven Schinner, Holger S Willenberg, Matthias Schott and Werner A Scherbaum \\ Department of Endocrinology, Diabetes and Rheumatology, University Hospital Düsseldorf, Moorenstrasse 5, 40225 Düsseldorf, Germany \\ (Correspondence should be addressed to S Schinner; Email: sven.schinner@uni-duesseldorf.de)
}

\begin{abstract}
Wnt-signaling has recently been identified as a regulator of a number of endocrine functions in health and disease in addition to its original attribution to developmental biology. Wnts are extracellular ligands on frizzled receptors and on lipoprotein receptor-related protein co-receptors. Ligand binding leads eventually to the activation of intracellular signaling cascades; based on the involvement of the transcriptional co-activator $\beta$-catenin it can be distinguished between canonical (i.e. $\beta$-catenin) and non-canonical Wnt-signaling. Recent studies revealed that canonical Wnt-signaling regulates the function of endocrine organs and contributes to a number of endocrine disorders. In this review, we would like to focus on a) recent mechanistic data on Wnts in pancreatic $\beta$-cell function; b) human genetic studies on Wnt signaling in type 2 diabetes mellitus; c) crosstalk between adipocytes and endocrine cells through Wnt-signaling molecules (with a focus on the role of Wnt-signaling in adrenocortical cells).
\end{abstract}

European Journal of Endocrinology 160 731-737

\section{Introduction: the Wnt-signaling pathway}

Wnt signaling molecules can bind to cell-surface receptors called frizzled and to lipoprotein receptorrelated protein (LRP) co-receptors (low density LRP). Frizzled receptors are G-protein-coupled seventransmembrane receptors. Binding to both receptors activates the canonical Wnt-signaling pathway. By targeting a complex containing adenomatous polyposis coli (APC) and axin the activation of this pathway leads to an inhibition of glycogen synthase kinase-3 (GSK3B). This results eventually in the stabilization of $\beta$-catenin. Subsequently, $\beta$-catenin, a transcriptional co-activator, translocates to the nucleus to activate T-cell factor (TCF)/lymphoid enhancer factor (LEF) transcription factors on canonical Wnt target-genes (see Fig. 1) (1). Originally, the Wnt signaling pathway has been identified as a regulator of embryogenesis and has thereafter been associated with tumor development (2). In addition, the role of Wnt-signaling agonists and antagonists in adipocyte differentiation has been subjected to a number of studies since its original description in 2000 (3-6). This has been the evidence linking Wnt-signaling with metabolic regulation.

\section{Wnts and $\beta$-cell function}

Wnt-signaling molecules are expressed in the human endocrine pancreas (7). Recent studies demonstrate that Wnt-signaling regulates insulin secretion and the proliferation of pancreatic $\beta$-cells. By using in vitro and in vivo approaches independent groups have recently reported that canonical Wnt signaling induces $\beta$-cell proliferation. Our group found adipocyte-derived Wntsignaling molecules to induce cyclin D1 transcription and the proliferation of $\beta$-cell lines and primary murine $\beta$-cells (see below) (8). In line with this, Rulifson et al. demonstrated that recombinant Wnt3a protein induced cell cycle regulators like cyclin D2 and Pitx2 and the proliferation rate in cultured $\beta$-cells (see Fig. 2). In addition, overexpression of active $\beta$-catenin was sufficient to induce proliferation markers and to increase $\beta$-cell mass in vivo using a transgenic mouse model. Conversely, inhibition of Wnt-signaling by overexpression of axin led to a decrease in the expression of cell cycle regulators and reduced $\beta$-cell expansion in vivo (9).

Furthermore, Liu \& Habener investigated the effects of glucagon-like peptide-1 (GLP-1) and the long acting GLP-1 receptor agonist exendin-4 (Exd4) on Wntsignaling and proliferation of pancreatic $\beta$-cells. They used TCF/LEF-driven reporter-gene assays and found GLP-1 and Exd4 to induce canonical Wnt-signaling in insulin-producing Ins-1-cells and primary murine $\beta$-cells. Consistently, activation of $\beta$-catenin was induced by Exd4. In chromatin immuno-precipitation assays, they showed that Exd4 stimulates the interaction of $\beta$-catenin and TCF7L2 with the cyclin D1 promoter. TCF7L2 is a Wnt-regulated transcription 

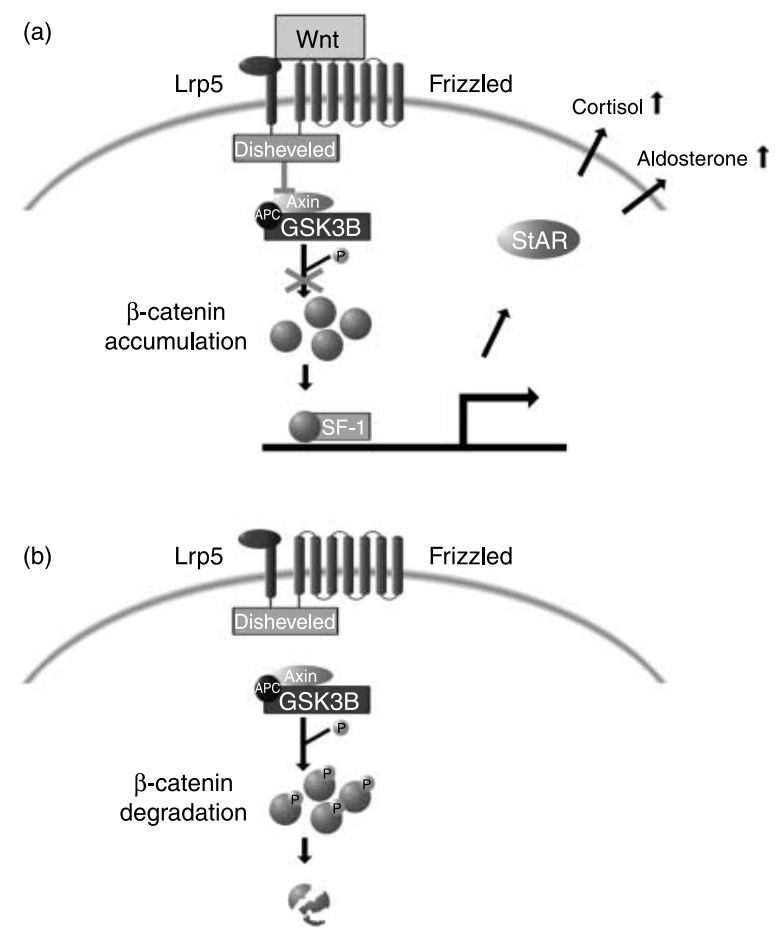

Figure 1 The intracellular Wnt-signaling cascade. (a) Wnt-ligands bind to frizzled cell-surface receptors and to LRP5 co-receptors. Ligand-binding activates disheveled and recruits the axin-APCGSK3B complex to the cell membrane, whereby the phosphorylation of $\beta$-catenin by GSK3B is inhibited. As a consequence of ligand binding $\beta$-catenin can eventually translocate to the nucleus to co-activate transcription factors on target genes. In adrenocortical cells $\beta$-catenin co-activates SF-1 driven transcription, for example at the StAR promoter resulting in an induction of steroidogenesis and eventually cortisol and aldosterone secretion. (b) In the absence of Wnt-ligand GSK3B phosphorylates $\beta$-catenin thereby inducing its degradation.

factor and polymorphisms in TCF7L2 are associated with an increased risk for type 2 diabetes (see below). Most importantly, inhibiting TCF 7L2 by stably transfecting a dominant-negative mutant inhibited the basal proliferation rate of Ins-1 cells and abolished the stimulatory effect of Exd4 on $\beta$-cell proliferation. How can GLP-1 activate canonical Wnt-signaling? Liu \& Habener carried out experiments using kinase inhibitors and overexpression of various dominantnegative kinase constructs in order to dissect the involved signaling pathways. They identified the protein kinase A (PKA), a known effector of GLP-1, to be required for the stimulation of Wnt-signaling by GLP-1. They found PKA to phosphorylate $\beta$-catenin at Ser-675 in response to GLP-1. In other studies, this phosphorylation has been shown to stabilize $\beta$-catenin and to enhance its transcriptional activity (10). Therefore, PKA appears to be a link between activation of the GLP-1 receptor and canonical Wnt-signaling in $\beta$-cells. In addition, protein kinase $\mathrm{B}(\mathrm{PKB})$ was found to mediate basal and Exd4-stimulated TOPFLASH transcription, indicating that both PKA and PKB are involved in linking GLP-1 to canonical Wnt-signaling (11).

In extension to this, Shu et al. demonstrated that a knock-down of TCF7L2 in isolated mouse and human islets by siRNA resulted in a blunted insulin-release in response to glucose in static incubation studies and in perifusion assays. Similarly, the effect of GLP-1 on glucose-stimulated insulin-secretion was decreased after depletion of TCF 7L2. In addition, depletion of TCF7L2 led to a decrease in proliferation and an increase in apoptosis of isolated human islets. Conversely, overexpression of TCF7L2 protected islets from glucotoxicity and cytokine toxicity with respect to glucose-induced insulin-secretion, proliferation, and apoptosis (12).

In line with these findings, Fujino and collegues reported that mice deficient in the Wnt co-receptor LRP5 had impaired glucose tolerance. These mice also showed blunted plasma insulin concentrations in response to glucose but no insulin resistance. Isolated islets from LRP5 deficient mice showed diminished glucose-induced insulin-secretion. However, the insulin response to $\alpha$-ketoisocaproate and tolbutamide were normal, whereas the ATP/ADP ratio under high-glucose exposure was decreased as compared with wild type islets. Glucose is metabolized in the glycolytic pathway to generate ATP which in turn inhibits the ATP-dependent $\mathrm{K}^{+}$-channel (so called 'glucose-sensing'). Tolbutamide and $\alpha$-ketoisocaproate inhibit the ATP-dependent $\mathrm{K}^{+}$-channel independently of the glycolytic pathway (the latter possibly indirectly by generating ATP from

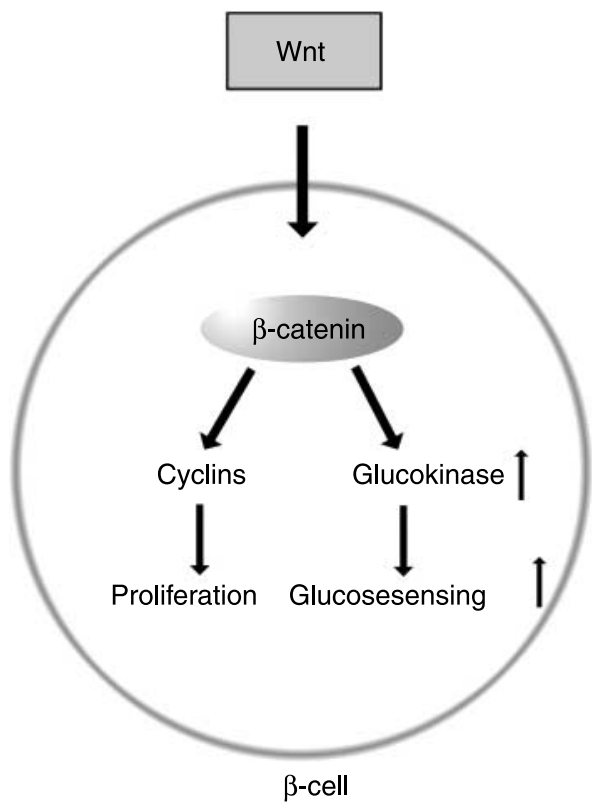

Figure 2 Wnt-signaling stimulates insulin secretion and $\beta$-cell proliferation. Activation of canonical ( $\beta$-catenin) Wnt-signaling induces the expression of the glukokinase gene, a key enzyme in glucose-sensing. In addition, canonical Wnt-signaling induces $\beta$-cell proliferation. 
mitochondria). Eventually, the inhibition of ATPdependent $\mathrm{K}^{+}$-channels leads to a calcium influx into $\beta$-cells, which then triggers insulin release.

Consistently, Fujino et al. found that treatment with Wnt-ligands increased glucose-induced insulinsecretion in wild-type islets but not in LRP5 deficient islets. These data suggested a deficit in glucose sensing in islets when canonical Wnt-signaling is impaired (13). Consistently, we demonstrated that $\beta$-catenin activates glucokinase gene transcription in pancreatic $\beta$-cells. Glucokinase is the crucial regulator of glucose-sensing in $\beta$-cells. Molecular studies suggest that $\beta$-catenin coactivates the transcriptional activity of PPARG at the glucokinase promoter (8) (see Fig. 2).

In contrast to these findings in postnatal mice, it has been shown that a depletion of $\beta$-catenin in the prenatal pancreas leads to acinar cell hypoplasia but did not change the mass and architecture of islets. Interestingly, these $\beta$-catenin deficient mice show normal glucose tolerance after birth (14). This discrepancy with Fujino's data (LRP $5^{-1-}$ mice) might be explained by $\beta$-cateninindependent signal-transduction downstream of LRP5. In this scenario, depletion of LRP5 might affect various signaling molecules in addition to the canonical $\beta$-catenin pathway contributing to the impaired insulin secretion. Another important difference between these two mouse models (LRP5- versus $\beta$-catenin-deficiency) is the age of the mice when tested for glucose tolerance and insulin secretion. Murtaugh et al. found normal glucose tolerance of the $\beta$-catenin deficient mice at 3-4 months of age. Fujino et al. analyzed glucose tolerance and islet function when the LRP 5 deficient mice were 6-8 months old. One might speculate that the $\beta$-cell decompensation and the insulin-deficient phenotype develop over time. However, at the present stage, these explanations remain speculative and further studies are needed to unravel the role of LRP 5 and $\beta$-catenin in islet biology.

\section{Human genetic studies on Wnt signaling in type 2 diabetes mellitus}

The above-mentioned in vitro and animal studies suggested a link between Wnt signaling and glucose metabolism. However, only very recently, human genetic studies actually supported the contribution of Wnt signaling to type 2 diabetes mellitus in humans. In 2006, two pioneer studies demonstrated that polymorphisms in TCF7L2, a Wnt-regulated transcription factor downstream from $\beta$-catenin, are associated with an increased risk for type 2 diabetes mellitus $(15,16)$. In genome wide association studies, the association of polymorphisms within TCF7L2 with diabetes mellitus type 2 has been confirmed. Presently, TCF7L2 is the strongest susceptibility gene for diabetes mellitus type 2 . The reported polymorphisms in TCF7L2 increased the risk of developing type 2 diabetes mellitus by $30-50 \%$ for each inherited allele which is almost twice the risk as for other diabetes candidate genes. Since then a number of large studies confirmed the association of TCF7L2 with diabetes mellitus in various ethnical groups (17-22). Among the various single nucleotide polymorphisms in TCF7L2, the variants rs 12255372 and rs7903146 have been identified to have the strongest association with diabetes mellitus type 2 .

Notably, all the identified SNPs in the TCF7L2 gene are located within intron regions. It is not yet clear how these intronic polymorphisms can cause altered expression or function of TCF $7 \mathrm{~L} 2$. Of note, TCF $7 \mathrm{~L} 2$ expression in pancreatic islets was found to be higher in diabetics than in non-diabetic subjects. Furthermore, TCF7L2 expression is upregulated in pancreatic islets in risk allelle carriers. Presently, we do not understand how these expression patterns can contribute to the pathophysiological processes in the context of the in vitro findings described above (for further reading on the association studies of TCF 7L2 and diabetes mellitus type 2 a number of excellent reviews can be recommended (23-25).

\section{How can these SNPs in TCF7L2 contribute to the diabetic phenotype?}

The polymorphisms in TCF 7L2 appears to affect insulin secretion rather than insulin sensitivity (26) and a link with the incretin system has been suggested. The proglucagon gene encodes for glucagon in pancreatic $\alpha$-cells and for GLP-1 in intestinal L-cells. In vitro studies by Jin's group have pointed out the role of $\beta$-catenin and TCF7L2 in the regulation of proglucagon gene transcription in enteroendocrine cells: they showed that lithium induced proglucagon mRNA expression and the transcription of the proglucagon gene promoter. As lithium acts as an inhibitor of GSK3B, thereby preventing the degradation of $\beta$-catenin they tested the direct effect of $\beta$-catenin on the proglucagon gene promoter. In fact, over-expression of constitutively active $\beta$-catenin activated the proglucagon gene promoter. Furthermore, TCF7L2 (also known as TCF4) binds to the proglucagon gene promoter together with $\beta$-catenin and constitutively active $\beta$-catenin coactivates transcription from a truncated proglucagon promoter carrying an intact TCF binding site. TCF $7 \mathrm{~L} 2$ activates the transcription of target genes when bound to $\beta$-catenin but acts as a transcriptional repressor in the absence of $\beta$-catenin as it lacks an activation domain. In fact, a dominant-negative TCF 7L2 mutant lacking the $\beta$-catenin binding domain repressed proglucagon gene transcription and GLP-1 synthesis. These studies underline the importance of $\beta$-catenin/TCF signaling in the regulation of proglucagon gene expression and GLP-1 synthesis $(27,28)$. Therefore, it has initially been speculated that polymorphisms of TCF7L2 might regulate GLP-1 expression and GLP-1 serum levels thereby indirectly 
modulating insulin release from pancreatic $\beta$-cells (15). This 'entero-insular' hypothesis is based on the interaction between enteroendocrine cells and pancreatic $\beta$-cells. This crosstalk is illustrated by the so called 'incretin effect': physiologically, intestinally administered glucose provokes a greater insulin release from $\beta$-cells than the same amount of glucose given i.v.ly. This is explained by the fact that enteroendocrine cells produce hormones like GLP-1 upon glucose stimulation which act directly on pancreatic $\beta$-cells to stimulate insulin secretion.

However, a study by Schäfer et al. found no effect of TCF7L2 polymorphisms on GLP-1 secretion in nondiabetic subjects (29). Similarly, Lyssenko et al. reported a blunted insulin response to oral and i.v. glucose load in patients carrying TCF7L2 polymorphisms, arguing against this interpretation of the entero-insular hypothesis (30). In the light of the work by Liu \& Habener, however, a role for TCF7L2 in modulating GLP-1 action within the $\beta$-cell seems more probable, given that TCF $7 L 2$ has been demonstrated to mediate GLP-1 effects in $\beta$-cells in vitro (11).

\section{Crosstalk between adipocytes and endocrine cells through Wnt-signaling molecules}

In 2000 Ross et al. showed in murine cell lines that inhibition of Wnt-signaling is a prerequisite for the differentiation of adipocytes (5). In a number of succeeding studies, it has been shown that constitutive endogenous Wnt-signaling keeps pre-adipocytes in an undifferentiated state $(3,6,31)$. Animal studies in mice confirmed the importance of Wnts for adipogenesis: transgenic overexpression of Wnt10b under the control of an adipocyte-specific promoter leads to reduced body fat content and impaired adipocyte maturation (32).

In addition to these auto-and paracrine effects on adipogenesis, we found Wnt signaling molecules secreted by adipocytes to be capable of acting on endocrine target cells. Adipocytes are endocrine active cells as they secrete signaling molecules to regulate metabolic functions. From a clinical point of view, it is well established that obesity is associated with metabolic co-morbidities: arterial hypertension - at least partly in consequence to hypersecretion of aldosterone and cortisol from adrenocortical cells - and pancreatic $\beta$-cell dysfunction are frequent in obesity.

At a cellular level, it has been shown that adipocytes can induce aldosterone and cortisol release from cultured adrenocortical cells (33). Given that Wnt3a and Wnt $10 b$ are secreted by mature human adipocytes, we performed in vitro assays to assess whether adipocytes are able to elicit Wnt-mediated responses on target cells. In fact, adipocytes were found to induce canonical Wnt-signaling in adrenocortical cells as well as in pancreatic $\beta$-cells $(8,34)$. Functionally, we could show that adipocytes induce the transcription of the StAR gene through secreted Wnt-signaling molecules and this led to an increase in aldosterone and cortisol release from adrenocortical cells (34). These observations suggest that adipocytes target endocrine cells through secreted Wnt-signaling molecules.

\section{How can adipocyte-derived Wnts reach endocrine cells?}

Wnt-signaling molecules have been detected in the systemic circulation in humans $(35,36)$ allowing for endocrine actions. However, paracrine actions might contribute to adipo-endocrine interactions as well: the adrenal gland is surrounded by adipose tissue and adipocytes are frequently found within the adrenal cortex (33). Similarly, obesity has been associated with increased adipocyte content within the pancreas in humans (37). Consistently, a systemic analysis of an obese, insulin resistant and hyperinsulinemic mouse model New Zealand-obese mouse revealed a massive increase of intra-pancreatic adipocyte deposition compared with wild-type animals. In addition, histological studies showed proximity of adipocytes and islets in these animals, suggesting paracrine effects on adipocytes on $\beta$-cells (38).

\section{Wnt signaling controls adrenal tumorigenesis and function}

The first in situ hybridization studies revealed that Xenopus homologues for pontin 52 and reptin 52, both of which are interaction partners of $\beta$-catenin are expressed in a subpopulation of neural crest cells that give rise to the adrenal medulla (39). On the contrary, immunoreactive $\beta$-catenin protein was found in the human fetal adrenal cortex (40). Molecular investigations documented that a variety of members of the Wnt-signaling pathway are also present within the human and mice adrenocortical tissues, among them Wnt4, dickkopf (DKK3), FZD1, FZD2, FZD3, and disheveled (in human) (DVL3) (41).

Soon it became evident that the nuclear translocation of $\beta$-catenin may be associated with adrenal tumorigenesis. Early data on the expression of $\beta$-catenin in adult human endocrine tumors showed that the nuclear accumulation of $\beta$-catenin may be associated with the Ki-67 (MiB-1) labeling index that reflects the proliferative activity in these neoplasms (42). Suprisingly, the analysis of exon 3 of the $\beta$-catenin gene did not reveal any mutations in these tumors. The same group also looked into adrenocortical adenomas. However, since they did not find nuclear accumulation of $\beta$-catenin in adrenocortical tumors, they did not perform mutational analyses (42). 


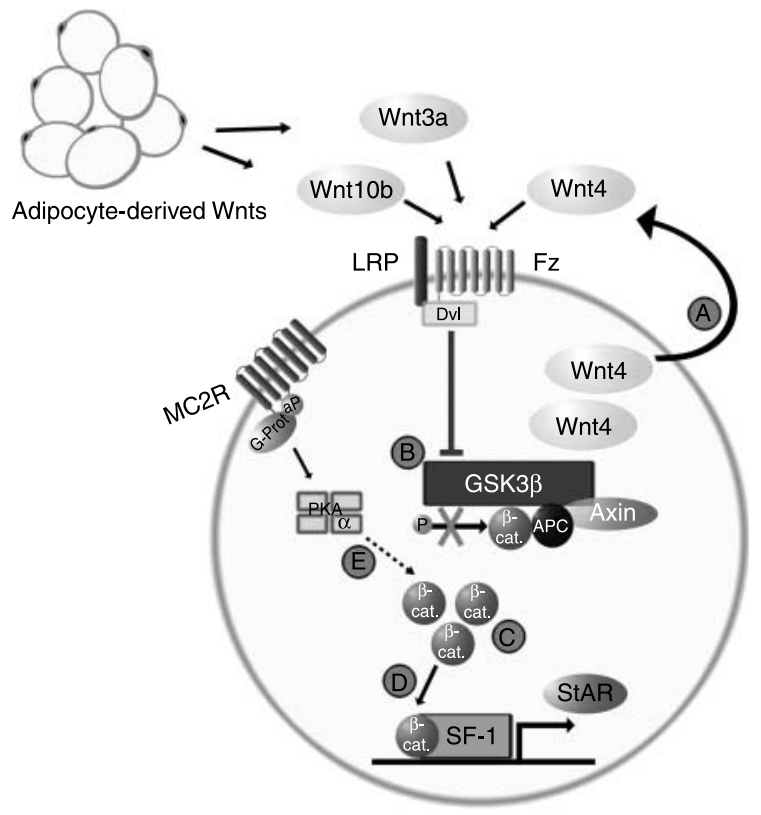

Figure 3 Wnts and adrenal function. This figure illustrates Wntactions in adrenocortical cell. On one hand, adipocyte-derived Wnt10b and Wnt3a can induce canonical Wnt-signaling in adrenocortical cells thereby stimulating steroidogenesis. On the other hand, in adrenocortical tumor cells different aberrations of Wnt-signaling may occur: $(A)$ autocrine action of differentially secreted Wnt-molecules, e.g., Wnt4; (B) mutations in the APC gene leading to impaired degradation of $\beta$-catenin; $(C)$ activating mutations in the $\beta$-catenin gene promotes cytoplasmic accumulation and nuclear translocation of the $\beta$-catenin protein; (D) high nuclear $\beta$-catenin immunoreactivity is observed in adrenocortical neoplasms; (E) constitutive activation of the cAMP protein kinase A pathway promotes $\beta$-catenin stabilization.

Later, it could be demonstrated that a considerable number of adrenocortical tumors showed abnormal immunohistological staining patterns for $\beta$-catenin and revealed indeed activating mutations in exon 3 of the $\beta$-catenin gene, frequently involving a serin residue (S45) (43-45). These mutations were found in sporadic benign and malignant adrenocortical neoplasms and also in the NCI-H295R cell line.

Interestingly, a study in patients with familial APC (FAP) who had extracolonic tumors, could not demonstrate mutations in the $\beta$-catenin gene but revealed somatic mutations in the APC gene, including a patient with an adrenocortical adenoma (46). Wnts signal via Dvl to disrupt the $\beta$-catenin destruction complex which includes axin, GSK3B, and APC. The APC protein destabilizes a protein complex, comprised of GSK3- $\beta$, axin, and Dvl, promoting phosphorylation and degradation of $\beta$-catenin (see Fig. 1). Retrospective and prospective studies in patients with FAP support the significance of this finding because an increased rate of adrenal tumorigenesis was found in patients with FAP and mutations in the APC gene $(47,48)$ (see Fig. 3).

of note, somatic $\beta$-catenin mutations were also detected in adenomas associated with primary pigmented nodular adrenocortical disease (PPNAD), further implicating $W n t / \beta$-catenin signaling in adrenal tumorigenesis $(44,49)$.

In vitro studies suggest that the Wnt-signaling pathway is involved in the control of adrenal steroidogenesis. WNT4 has been shown to increase the steroidogenic enzymes $17 \alpha$-hydroxylase and aldosterone synthase in the absence of cyclic AMP (50). We found that fat-cell conditioned-medium that contained WNT3 $a$ and WNT1Ob molecules stimulated adrenocortical cells and synthesis of aldosterone in vitro (34). In agreement, WNT4-deficiency results in the dysfunction of the adrenal cortex and in reduced plasma levels of aldosterone (51). Of note, recent data show that Wnt 4 may be differentially regulated by angiotensin II and abundant expression of Wnt4 was found in aldosterone-producing adenomas (52).

The upregulation of steroidogenic enzymes in response to Wnt-molecules is mediated by $\beta$-catenindependent activation of steroidogenic factor-1 and expression of the StAR $(34,53)$ (see Fig. 1).

\section{Conclusion}

The Wnt-signaling pathway has been shown to regulate a number of endocrine functions: molecular approaches performed in vitro and in vivo as well as human genetics studies have confirmed a crucial role for Wnt-signaling in adipogenesis, pancreatic $\beta$-cell function and diabetes mellitus type 2 as well as adrenal physiology. Noteably, adipocytes have been found to secrete Wnt-signaling molecules to regulate the function of endocrine target cells, thereby suggesting that Wnts might act as adipokines.

\section{Declaration of interest}

The authors declare that there is no conflict of interest.

\section{Funding}

This work was supported by grants of the Eberhard-Igler-Stiftung and Walter-Clawiter-Stiftung Duesseldorf, Germany, to H S Willenberg and S Schinner and by a grant of the Doktor Robert Pfleger-Stiftung, Bamberg, Germany, to H S Willenberg. This work was furthermore supported by a grant of the Forschungskommission of the HeinrichHeine-University Düsseldorf, Germany to S Schinner.

\section{Acknowledgements}

We thank Markus Kühn for excellent technical assistance.

\section{References}

1 Gordon MD \& Nusse R. Wht signaling: multiple pathways, multiple receptors, and multiple transcription factors. Journal of Biological Chemistry $200628122429-22433$. 
2 Logan CY \& Nusse R. The Wnt signaling pathway in development and disease. Annual Review of Cell and Developmental Biology 2004 20 781-810.

3 Longo KA, Kennell JA, Ochocinska MJ, Ross SE, Wright WS \& MacDougald OA. Wnt signaling protects 3T3-L1 preadipocytes from apoptosis through induction of insulin-like growth factors. Journal of Biological Chemistry 2002277 38239-38244.

4 MacDougald OA \& Mandrup S. Adipogenesis: forces that tip the scales. Trends in Endocrinology and Metabolism 200213 5-11.

5 Ross SE, Hemati N, Longo KA, Bennett CN, Lucas PC, Erickson RL \& MacDougald OA. Inhibition of adipogenesis by Wnt signaling. Science 2000289 950-953.

6 Christodoulides C, Laudes M, Cawthorn WP, Schinner S, Soos M, O'Rahilly S, Sethi JK \& Vidal-Puig A. The Wnt antagonist Dickkopf-1 and its receptors are coordinately regulated during early human adipogenesis. Journal of Cell Science 2006119 2613-2620.

7 Heller RS, Klein T, Ling Z, Heimberg H, Katoh M, Madsen OD \& Serup P. Expression of Wnt, frizzled, sFRP, and DKK genes in adult human pancreas. Gene Expression 200311 141-147.

8 Schinner S, Ulgen F, Papewalis C, Schott M, Woelk A, Vidal-Puig A \& Scherbaum WA. Regulation of insulin secretion, glucokinase gene transcription and beta cell proliferation by adipocyte-derived Wnt signalling molecules. Diabetologia 200851 147-154.

9 Rulifson IC, Karnik SK, Heiser PW, Ten Berge D, Chen H, Gu X, Taketo MM, Nusse R, Hebrok M \& Kim SK. Wnt signaling regulates pancreatic beta cell proliferation. PNAS 2007104 6247-6252.

10 Hino S, Tanji C, Nakayama KI \& Kikuchi A. Phosphorylation of beta-catenin by cyclic AMP-dependent protein kinase stabilizes beta-catenin through inhibition of its ubiquitination. Molecular and Cellular Biology 200525 9063-9072.

11 Liu Z \& Habener JF. Glucagon-like peptide-1 activation of TCF7L2dependent Wnt signaling enhances pancreatic beta cell proliferation. Journal of Biological Chemistry 2008283 8723-8735.

12 Shu L, Sauter NS, Schulthess FT, Matveyenko AV, Oberholzer J \& Maedler K. Transcription factor 7 -like 2 regulates beta-cell survival and function in human pancreatic islets. Diabetes 2008 $\mathbf{5 7} 645-653$.

13 Fujino T, Asaba H, Kang MJ, Ikeda Y, Sone H, Takada S, Kim DH, Ioka RX, Ono M, Tomoyori H, Okubo M, Murase T, Kamataki A, Yamamoto J, Magoori K, Takahashi S, Miyamoto Y, Oishi H, Nose M, Okazaki M, Usui S, Imaizumi K, Yanagisawa M, Sakai J \& Yamamoto TT. Low-density lipoprotein receptor-related protein 5 (LRP5) is essential for normal cholesterol metabolism and glucoseinduced insulin secretion. PNAS 2003100 229-234.

14 Murtaugh LC, Law AC, Dor Y \& Melton DA. Beta-catenin is essential for pancreatic acinar but not islet development. Development 2005132 4663-4674.

15 Grant SF, Thorleifsson G, Reynisdottir I, Benediktsson R, Manolescu A, Sainz J, Helgason A, Stefansson H, Emilsson V, Helgadottir A, Styrkarsdottir U, Magnusson KP, Walters GB, Palsdottir E, Jonsdottir T, Gudmundsdottir T, Gylfason A, Saemundsdottir J, Wilensky RL, Reilly MP, Rader DJ, Bagger Y, Christiansen C, Gudnason V, Sigurdsson G, Thorsteinsdottir U, Gulcher JR, Kong A \& Stefansson K. Variant of transcription factor 7-like 2 (TCF7L2) gene confers risk of type 2 diabetes. Nature Genetics 200638 320-323.

16 Florez JC, Jablonski KA, Bayley N, Pollin TI, de Bakker PI, Shuldiner AR, Knowler WC, Nathan DM \& Altshuler D. TCF7L2 polymorphisms and progression to diabetes in the diabetes prevention program. New England Journal of Medicine 2006355 241-250.

17 Cauchi S, El AY, Choquet H, Dina C, Krempler F, Weitgasser R, Nejjari C, Patsch W, Chikri M, Meyre D \& Froguel P. TCF7L2 is reproducibly associated with type 2 diabetes in various ethnic groups: a global meta-analysis. Journal of Molecular Medicine 2007 $85777-782$.

18 Cauchi S, Meyre D, Dina C, Choquet H, Samson C, Gallina S, Balkau B, Charpentier G, Pattou F, Stetsyuk V, Scharfmann R, Staels B, Fruhbeck G \& Froguel P. Transcription factor TCF7L2 genetic study in the French population: expression in human betacells and adipose tissue and strong association with type 2 diabetes. Diabetes 200655 2903-2908.

19 Hayashi T, Iwamoto Y, Kaku K, Hirose H \& Maeda S. Replication study for the association of TCF7L2 with susceptibility to type 2 diabetes in a Japanese population. Diabetologia 2007 50 980-984.

20 Helgason A, Palsson S, Thorleifsson G, Grant SF, Emilsson V, Gunnarsdottir S, Adeyemo A, Chen Y, Chen G, Reynisdottir I, Benediktsson R, Hinney A, Hansen T, Andersen G, BorchJohnsen K, Jorgensen T, Schafer H, Faruque M, Doumatey A, Zhou J, Wilensky RL, Reilly MP, Rader DJ, Bagger Y, Christiansen C, Sigurdsson G, Hebebrand J, Pedersen O, Thorsteinsdottir U, Gulcher JR, Kong A, Rotimi C \& Stefansson K. Refining the impact of TCF7L2 gene variants on type 2 diabetes and adaptive evolution. Nature Genetics 200739 218-225.

21 Steinthorsdottir V, Thorleifsson G, Reynisdottir I, Benediktsson R, Jonsdottir T, Walters GB, Styrkarsdottir U, Gretarsdottir S, Emilsson V, Ghosh S, Baker A, Snorradottir S, Bjarnason H, Ng MC, Hansen T, Bagger Y, Wilensky RL, Reilly MP, Adeyemo A, Chen Y, Zhou J, Gudnason V, Chen G, Huang H, Lashley K, Doumatey A, So WY, Ma RC, Andersen G, Borch-Johnsen K, Jorgensen T, van Vliet-Ostaptchouk JV, Hofker MH, Wijmenga C, Christiansen C, Rader DJ, Rotimi C, Gurney M, Chan JC, Pedersen O, Sigurdsson G, Gulcher JR, Thorsteinsdottir U, Kong A \& Stefansson K. A variant in CDKAL1 influences insulin response and risk of type 2 diabetes. Nature Genetics 200739 770-775.

22 Chang YC, Chang TJ, Jiang YD, Kuo SS, Lee KC, Chiu KC \& Chuang LM. Association study of the genetic polymorphisms of the transcription factor 7-like 2 (TCF7L2) gene and type 2 diabetes in the Chinese population. Diabetes 200756 2631-2637.

23 Lyssenko V. The transcription factor 7-like 2 gene and increased risk of type 2 diabetes: an update. Current Opinion in Clinical Nutrition and Metabolic Care 200811 385-392.

24 Florez JC. Newly identified loci highlight beta cell dysfunction as a key cause of type 2 diabetes: where are the insulin resistance genes? Diabetologia $2008 \mathbf{5 1}$ 1100-1110.

25 Jin T. The Wnt signalling pathway and diabetes mellitus. Diabetologia $2008 \mathbf{5 1} 1771-1780$.

26 Wegner L, Hussain MS, Pilgaard K, Hansen T, Pedersen O, Vaag A \& Poulsen P. Impact of TCF7L2 rs7903146 on insulin secretion and action in young and elderly Danish twins. Clinics in Endocrinology and Metabolism 200893 4013-4019.

27 Yi F, Brubaker PL \& Jin T. TCF-4 mediates cell type-specific regulation of proglucagon gene expression by beta-catenin and glycogen synthase kinase-3beta. Journal of Biological Chemistry $20052801457-1464$.

28 Ni Z, Anini Y, Fang X, Mills G, Brubaker PL \& Jin T. Transcriptional activation of the proglucagon gene by lithium and beta-catenin in intestinal endocrine L cells. Journal of Biological Chemistry 2003 278 1380-1387.

29 Schafer SA, Tschritter O, Machicao F, Thamer C, Stefan N, Gallwitz B, Holst JJ, Dekker JM, 't Hart LM, Nijpels G, van Haeften TW, Haring HU \& Fritsche A. Impaired glucagon-like peptide-1-induced insulin secretion in carriers of transcription factor 7-like 2 (TCF7L2) gene polymorphisms. Diabetologia 2007 $502443-2450$.

30 Lyssenko V, Lupi R, Marchetti P, Del GS, Orho-Melander M, Almgren P, Sjogren M, Ling C, Eriksson KF, Lethagen AL, Mancarella R, Berglund G, Tuomi T, Nilsson P, Del PS \& Groop L. Mechanisms by which common variants in the TCF7L2 gene increase risk of type 2 diabetes. Journal of Clinical Investigation $20071172155-2163$.

31 Ross SE, Erickson RL, Gerin I, DeRose PM, Bajnok L, Longo KA, Misek DE, Kuick R, Hanash SM, Atkins KB, Andresen SM, Nebb HI, Madsen L, Kristiansen K \& MacDougald OA. Microarray analyses during adipogenesis: understanding the effects of Wnt signaling on adipogenesis and the roles of liver $X$ receptor alpha in adipocyte metabolism. Molecular and Cellular Biology 200222 5989-5999. 
32 Longo KA, Wright WS, Kang S, Gerin I, Chiang SH, Lucas PC, Opp MR \& MacDougald OA. Wnt10b inhibits development of white and brown adipose tissues. Journal of Biological Chemistry $200427935503-35509$.

33 Ehrhart-Bornstein M, Lamounier-Zepter V, Schraven A, Langenbach J, Willenberg HS, Barthel A, Hauner H, McCann SM, Scherbaum WA \& Bornstein SR. Human adipocytes secrete mineralocorticoid-releasing factors. PNAS $2003 \mathbf{1 0 0}$ 14211-14216.

34 Schinner S, Willenberg HS, Krause D, Schott M, Lamounier-Zepter V, Krug AW, Ehrhart-Bornstein M, Bornstein SR \& Scherbaum WA. Adipocyte-derived products induce the transcription of the StAR promoter and stimulate aldosterone and cortisol secretion from adrenocortical cells through the Wnt-signaling pathway. International Journal of Obesity 200731 864-870.

35 Tian E, Zhan F, Walker R, Rasmussen E, Ma Y, Barlogie B \& Shaughnessy JD Jr. The role of the Wnt-signaling antagonist DKK1 in the development of osteolytic lesions in multiple myeloma. New England Journal of Medicine 2003349 2483-2494.

36 Berndt T, Craig TA, Bowe AE, Vassiliadis J, Reczek D, Finnegan R, Jan De Beur SM, Schiavi SC \& Kumar R. Secreted frizzled-related protein 4 is a potent tumor-derived phosphaturic agent. Journal of Clinical Investigation 2003112 785-794.

37 Olsen TS. Lipomatosis of the pancreas in autopsy material and its relation to age and overweight. Acta Pathologica et Microbiologica Scandinavica. Section A 1978 86A 367-373.

38 Ulgen F, Scherbaum WA, Partke HJ, Bornstein SR \& Schinner S. Intrapancreatic adipocyte deposition in a mouse model of the metabolic syndrome. Hormone and Metabolic Research $2008 \mathbf{4 0}$ 507-509.

39 Etard C, Wedlich D, Bauer A, Huber O \& Kuhl M. Expression of Xenopus homologs of the beta-catenin binding protein pontin 52 . Mechanisms of Development 200094 219-222.

40 Eberhart CG \& Argani P. Wnt signaling in human development: beta-catenin nuclear translocation in fetal lung, kidney, placenta, capillaries, adrenal, and cartilage. Pediatric and Developmental Pathology 20014 351-357.

41 Suwa T, Chen M, Hawks CL \& Hornsby PJ. Zonal expression of dickkopf-3 and components of the Wnt signalling pathways in the human adrenal cortex. Journal of Endocrinology $2003 \mathbf{1 7 8}$ 149-158.

42 Semba S, Kusumi R, Moriya T \& Sasano H. Nuclear accumulation of B-catenin in human endocrine tumors: association with Ki-67 (MIB-1) proliferative activity. Endocrine Pathology 200011 243-250.

43 Tissier F, Cavard C, Groussin L, Perlemoine K, Fumey G, Hagnere AM, Rene-Corail F, Jullian E, Gicquel C, Bertagna X, Vacher-Lavenu MC, Perret C \& Bertherat J. Mutations of beta-catenin in adrenocortical tumors: activation of the Wnt signaling pathway is a frequent event in both benign and malignant adrenocortical tumors. Cancer Research $2005657622-7627$.

44 Tadjine M, Lampron A, Ouadi L, Horvath A, Stratakis CA \& Bourdeau I. Detection of somatic beta-catenin mutations in primary pigmented nodular adrenocortical disease (PPNAD). Clinical Endocrinology $200869367-373$.

45 Tadjine M, Lampron A, Ouadi L \& Bourdeau I. Frequent mutations of beta-catenin gene in sporadic secreting adrenocortical adenomas. Clinical Endocrinology 200868 264-270.

46 Blaker H, Sutter C, Kadmon M, Otto HF, Von Knebel-Doeberitz M, Gebert J \& Helmke BM. Analysis of somatic APC mutations in rare extracolonic tumors of patients with familial adenomatous polyposis coli, genes chromosomes. Cancer 2004 41 93-98.

47 Marchesa P, Fazio VW, Church JM \& McGannon E. Adrenal masses in patients with familial adenomatous polyposis. Diseases of the Colon and Rectum 199740 1023-1028.

48 Smith TG, Clark SK, Katz DE, Reznek RH \& Phillips RK. Adrenal masses are associated with familial adenomatous polyposis. Diseases of the Colon and Rectum 200043 1739-1742.

49 Gaujoux S, Tissier F, Groussin L, Libe R, Ragazzon B, Launay P, Audebourg A, Dousset B, Bertagna X \& Bertherat J. Wnt/beta-catenin and $3^{\prime}, 5^{\prime}$-cyclic adenosine $5^{\prime}$-monophosphate/protein kinase A signaling pathways alterations and somatic beta-catenin gene mutations in the progression of adrenocortical tumors. Journal of Clinical Endocrinology and Metabolism 200893 4135-4140.

50 Chen M \& Hornsby PJ. Adenovirus-delivered DKK3/Wnt4 and steroidogenesis in primary cultures of adrenocortical cells. Hormone and Metabolic Research 200638 549-555.

51 Heikkila M, Peltoketo H, Leppaluoto J, Ilves M, Vuolteenaho O \& Vainio S. Wnt-4 deficiency alters mouse adrenal cortex function, reducing aldosterone production. Endocrinology 2002 $1434358-4365$.

52 Kuulasmaa T, Jaaskelainen J, Suppola S, Pietilainen T, Heikkila P, Aaltomaa S, Kosma VM \& Voutilainen R. Wnt-4 mRNA expression in human adrenocortical tumors and cultured adrenal cells. Hormone and Metabolic Research $200840668-673$.

53 Gummow BM, Winnay JN \& Hammer GD. Convergence of Wnt signaling and steroidogenic factor-1 (SF-1) on transcription of the rat inhibin alpha gene. Journal of Biological Chemistry $2003 \mathbf{2 7 8}$ 26572-26579.

Received 21 February 2009

Accepted 24 February 2009 